\title{
Corporate Indebtedness of Non-Financial Corporations in Bulgaria
}

\section{Yanko Hristozov*}

\section{Summary}

Corporate indebtedness is a particularly important indicator of the financial condition of enterprises, but its analysis is often underestimated, especially when it comes to its levels for entire economies. An example of this is Bulgaria, which does not analyze the indicator and does not prepare statistics on the issue. This is despite the signals in several consecutive EC reports of excessive levels of corporate indebtedness. The aim of the article is to analyze the corporate indebtedness at the macro level for the period 2008-2018 using absolute and relative indicators and looking for correlations with other economic indicators. The object of study are nonfinancial enterprises in Bulgaria. The research thesis is based on the assumption that the assessment of corporate indebtedness based only on absolute indicators is wrong and would distort the conclusions and opinions of the users interested in this information. Therefore, to assess corporate indebtedness, absolute indicators, absolute indicators per one enterprise and relative indicators must be combined and analyzed, and their relationships with other key macroeconomic and financial indicators should be identified.
Keywords: Corporate Debt, Indebtedness, Intercompany Indebtedness

JEL: G30

\section{Introduction}

Even before the economic crisis of

2007, caused by the financial sector, several studies identified the alarming trend of increasing corporate debt, respectively of corporate indebtedness in Bulgaria and in the region. Debt accumulation is largely driven by easy access to borrowed capital and coincides with a strong drive for new investment, which, however, has not led to sustainable growth in the region's economies. The same trend has continued and intensified since the financial crisis unfolded. The same trend has continued and intensified since the financial crisis unfolded. Thus, the legacy of high debt remained in corporate balance sheets, which made companies vulnerable to changes in risks and declining demand and sales revenues, respectively. The global financial and economic crisis has put the development of enterprises in Bulgaria and around the world in a controllable environment that is difficult to predict. Today these enterprises face new challenges. A decade later, it is necessary to assess exactly how it has affected the corporate indebtedness of individual economic sectors, especially at a time when there is increasing talk of the next economic crisis caused by the global

\footnotetext{
Department of Finance, UNWE
} 


\section{Articles}

CoVid-19 pandemic, which in 2020 is already a fact.

The survey of the indebtedness of Bulgarian non-financial corporations is related to the lack of such a large-scale survey in Bulgaria. A significant problem of the Bulgarian state and of the institutions responsible for statistics and finance is the lack of a generalized analysis of the state of corporate indebtedness. A survey on corporate indebtedness until 2014 was prepared by the Bulgarian Industrial Association but has been discontinued in recent years. The link between indebtedness and liquidity is becoming increasingly apparent, and Bulgarian companies are dealing with their liquidity problems, increasing liabilities to suppliers, related companies and group companies and other creditors, thus increasing intra-corporate indebtedness. The main argument in favor of the study is the possibility to prepare industry-wide values of key relative financial indicators measuring the indebtedness of enterprises in Bulgaria. Subsequently, threshold (reference) indicative values (of the respective indicators, for the respective industries) could be defined to generate a signal requiring economic and/or legal intervention by the macro policy makers.

\section{Methods and Methodology}

The solution of the set tasks, through which the research goal is realized, is both through the strict adherence to the general scientific methods of research and through the application of the special research tools, characteristic of the economic studies and in particular of financial analysis. In this regard, the main applied methods are:

- The method of analysis in its varieties:

o Comparative analysis: will compare absolute, relative, and other macroeconomic indicators related to corporate indebtedness.
O Descriptive analysis: important characteristics of corporate indebtedness will be described.

- The method of synthesis. Based on this method, the established microeconomic dependencies are extrapolated at the meso- and macroeconomic level.

- Inductive-probabilistic (synthesis) and deductive-hypothetical methods (analysis). They will seek to identify the cause-and-effect effect on indebtedness. These approaches are the basis of the overall study, thus contributing to its implementation in full.

General scientific methods, and observation and historical analysis, have been used as the basis for special research methods. In this regard, the collection of empirical data, the study of the academic literature on research issues are the basis to justify the research methodology and to ensure the correct conduct of the research. The method of abstraction allows for the elimination of non-essential determinants and the construction of certain models (modeling method), through which to explain the causal relationship, to test certain assumptions and to make specific recommendations. This is the basis on which the author's assumptions are verified.

The data contained in the statements of financial position and comprehensive income provide a good opportunity for an expanded and in-depth study of the financial condition of the enterprise. The availability of reports from two or more periods creates conditions for analysis and assessment of the financial condition in perspective, i.e. allows the disclosure of key trends in the development of enterprises in one direction or another.

The survey includes data on the sectors representing non-financial corporations according to the KID-2008 classifier (NSI, 2008). These are sectors A, B, C, D, E, F, 


\section{Articles}

$\mathrm{G}, \mathrm{H}, \mathrm{I}, \mathrm{J}, \mathrm{L}, \mathrm{M}, \mathrm{N}, \mathrm{S}$. The time limits that are set for the research period are from 2008 to 2018. This period is clear. The classifier of economic activities according to the NSI in this form is valid after 2008 until now. And the information that provides the analysis is provided only for the purposes of the survey in raw form in the form of a consolidated statement of financial position and statement of comprehensive income from the NSI and the latest data are for 2018. Data for 2019 are expected to be available in February 2021. The period is long enough to give a clear idea of the situation with corporate indebtedness, there is no research on the topic in the Bulgarian scientific literature of such a scale.

The immediate task of this part of the research is to try to measure and analyze the indebtedness, applying different methodological options and looking for an alternative point of view. Initially, it will be measured in absolute values, i.e. historical analysis of the changes in the total liabilities of the enterprises, which will be considered first from the point of view of the maturity of the liabilities (long-term and short-term), followed by an analysis of the individual types of liabilities of the enterprises according to their aggregate structure. Absolute indicators refer to the data on liabilities of enterprises provided in the annual financial statements in nominal value. That is, it should be borne in mind that inflation is not considered. It should also be borne in mind that the statement of financial position is prepared as of 31 December based on the information on the balances on the accounts, i.e. the data used are static. The company liabilities presented in the statements of financial position of enterprises are the following: Bond loans; Liabilities to financial institutions; Advances provided; Liabilities to suppliers; Liabilities under policies; Liabilities to group companies; Liabilities to related companies;
Corporate Indebtedness of Non-Financial Corporations

in Bulgaria

Other liabilities, incl. Insurance liabilities, Tax liabilities and Liabilities to staff.

The levels of dangerous and risky for the economy and enterprises intercompany indebtedness will be measured, which according to the methodology of the Bulgarian Industrial Association (2014) includes the following types of liabilities: bond loans; advances provided; liabilities to suppliers; liabilities under policies; liabilities to group companies; liabilities to related companies; other liabilities, not incl. insurance liabilities, tax liabilities and liabilities to staff.

The total corporate and intercompany indebtedness will be examined in a second way, considering the number of enterprises in the statistical sample, i.e. these two indicators will be measured based on one enterprise in the sector. This will make it possible to refine the data and give a new perspective on the results.

The third possibility for measuring the indebtedness, which will be applied, is through the measurement and analysis of the so-called indebtedness ratios in the enterprise, which will be tested for nonfinancial enterprises in order to analyze their dynamics and take into account the sectoral conditionality of the results obtained. Debt ratios are important and show the extent to which management uses financial leverage in the company, also reflect the company's ability to repay its obligations in the long run. They are also related to the discussion of the capital structure and the effects on the value of the enterprise. (Nenkov, D., Hristozov, Y., 2020). Although indicators are often used in practice to analyze the financial condition of an enterprise, they can be applied to entire sectors and provide a different perspective in the analysis, as in this case. A similar practice is applied in other analyzes. The most appropriate indicators for measuring indebtedness are debt to equity ratio, debt 


\section{Articles}

to assets ratio, long-term debt to assets ratio and interest coverage ratio.

To look for links to key macroeconomic and financial indicators, a comparison is made of the changes in them compared to the change in debt. Such indicators for example are GDP, investments, net sales revenues, receivables. Data on current prices are taken from the NSI data. There is a small and insignificant difference between the NSI and Eurostat data on Bulgaria's GDP in national currency. The main goal in deriving the relative indicators will be to outline sector averages for each ratio for the whole period studied, as well as average levels of indicators for all nonfinancial corporations.

\section{Corporate Debt}

The money supply in the conditions of a currency board can increase in several ways, but the main opportunities are from external entities and through lending within the banking system (Hristov, M., 2013). On the other hand, reducing the velocity of money circulation causes adverse side effects. It is the basis of the so-called. shadow economy, i.e. unregulated economic activity. (Minassian, G., 2013). In this regard, the issues of financing business and increasing indebtedness are essential not only for the development of Bulgarian enterprises, but also for the economy. An important factor for the economic activity of the countries is the ability of non-financial enterprises from different economic sectors to obtain the necessary working capital and investment funds. The companies receive attracted capital not only from financial and credit institutions but also through the issue of debt financial instruments and attracted capital from other creditors such as suppliers (trade credits), related companies, group companies, bond loans, overdue liabilities to staff, government and others. In periods of economic growth, the easy access of economic entities to excessive lending through bank and commercial loans raises the desire to sell goods and services at levels higher than their demand. This causes a significant increase in corporate indebtedness and creates a risk of so-called "Chain indebtedness", in which the inability of a creditor to claim his claims puts him in a difficult situation. The issue is so important that the measures that need to be taken by companies and especially by the state cannot be postponed, because there is a risk that Bulgaria will face the danger of serious economic imbalances.

Entrepreneurs and managers need to think about the many tools they can use to finance a company (Welch, I., 2009). Debt management is a key aspect of a company's financial management (Nenkov, D., Hristozov, Y., 2020). The indebtedness of the company is expressed by the amount of borrowed capital used to obtain profitability. Basically, the financial analysis of the company focuses on indebtedness, insofar as it generates the payment of interest and principal repayments in the long run. In this regard, the interests of the owners (shareholders) and creditors usually do not coincide and are contradictory. The owners strive to attract the maximum amount of foreign funds to expand the business as much as possible. They claim more confidence from creditors, arguing with the high future results they will achieve. Creditors are generally responsible for the efficient use of foreign funds (savers' deposits, etc.) and therefore require maximum guarantees of promises of high results. In this sense, they are more skeptical and are guided by strict rules that consider the risks of the respective investments. They see equity as a buffer for risk-taking. With the help of indebtedness indicators, complex relationships between owners and creditors can be revealed. In most cases, there is a difference between 


\section{Articles}

the money companies need and the money they generate internally. This difference is the so-called financial deficit. To compensate for the deficit, companies must either increase their equity or borrow foreign capital. So, they face two main financing decisions: How much profit should be reinvested in the business, not paid as dividends, and what part of the deficit should be financed through loans? An important question is how much the company should borrow, but also what debt to create, short-term or long-term? In this regard, according to E. Raykov (2017), working capital management should draw the attention of shareholders to the possibilities for achieving effective results by optimizing the internal resources of business at the micro level in the face of significant constraints and shocks from the external environment at the macroeconomic level.

The cash flow management function is related to the control over the receipts through the trade policy and the policy for monitoring and collection of the receivables, as well as subsequent planning and daily adjustment of the outgoing payments according to the possibilities of the company. This function is an expression of operational financial management in action. The impact on cash inflows is related to a commitment to frame the trade credit in accordance with the risk assessment of the client portfolio and the restrictions on access to finance, which is necessary to secure current assets (Raykov, E., 2017).

An external manifestation of financial stability is the solvency of the enterprise, revealing its ability to repay in full its liabilities, which may be short-term or long-term when they become due. The statement of financial position of an enterprise may show good liquidity and the enterprise may be in a state of insolvency. This is because the liquidity established from the balance sheet
Corporate Indebtedness of Non-Financial Corporations

in Bulgaria

data expresses the static situation, and not only that. The current assets available at the balance sheet date may be sufficient to settle current liabilities and yet the company will be unable to repay its liabilities at maturity due to the periods of turnover of these assets. If liquidity ratios are related to current solvency, then solvency ratios are used to characterize the ability of firms to pay their liabilities in the long run. They are also used both in the analysis of the financial condition and in the analysis of the financial stability of enterprises. Debt ratios, and hence the state of solvency, make it possible to assess the ability of the company to pay its short-term and long-term debts; to attract additional capital without risk of losing its financial stability; to maintain its independence from creditors.

Debt creation is a process that stimulates economic growth, but up to a certain point in the long run, persistently high indebtedness would lead to negative results (Cecchetti, St., Mohanty, M., Zampolli, F., 2011). The essential problem is not the company obligations as a whole, but the internal company debt, which creates risk and immobilizes the capital of the companies, and when the phenomenon is massive, there is a danger for the future economic development of the country and the business. Trade credit increases intrafirm indebtedness, but trade payables remain a traditional and frequently used source of corporate financing. Along with the benefits of using commercial credit, the excessive increase of companies' indebtedness to suppliers and the increase in the share of overdue liabilities is associated with a number of adverse effects for the creditor: costs for protection against bad debts; loss of profitability and liquidity; missed benefits from shrinking credit sales; threat of insolvency at macroeconomic level as well, such as: risk of mass bankruptcies in certain sectors; shrinking economy, employment and budget 


\section{Articles}

revenues; risk to the stability of the financial system, etc.

The maturity of corporate debt should not be ignored because it is essential to clarify and is of interest to corporate finance. This issue has become particularly relevant after the financial crises and shows a significant mismatch between asset maturity and debt maturity. More importantly, it turns out that companies are willing to finance fixed assets with short-term debt, thus violating the golden balance of equity to finance fixed assets entirely with long-term debt (Adachi-Sato, M., Vithessonthi, Ch ., 2019). The choice of debt maturity can have an important effect on the value and risk of the company. The inappropriate choice of this term may expose firms to potential difficulties in changing and fluctuating interest rates and may make it difficult to seek valuable growth opportunities (Orman, C., Koksal, B., 2017). The reason for the simultaneous financing of non-financial enterprises with bank and trade loans is the difference in maturities, as one is rather shortterm and the other long-term (Cole, R., 2010). The access and conditions for obtaining the two types of lending also differ, usually companies with liquidity and debt difficulties resort more often to indebtedness to suppliers and other non-bank lenders.

The macroeconomic criteria for estimating debt according to the European Central Bank (ECB, https://www.ecb.europa.eu) are based on the financial accounts of countries or economic zones, as they provide comprehensive data on the financial assets and liabilities of the economy, divided by institutional sector (i.e. households, nonfinancial corporations, financial corporations and government). In the EU, financial statements are prepared in accordance with the concepts and definitions established by the European System of Accounts 2010 (ESA 2010), which ensures comparability between countries. Several approaches to debt analysis are used for the non-financial corporations' sector. These approaches are used to analyze economic and financial stability by the European Central Bank, the European Systemic Risk Board, and the Bank for International Settlements. In general, debt is defined as all liabilities that require the payment of interest or principal from the debtor to the creditor. Debt measures for nonfinancial corporations include all liabilities from loans received and debt securities issued. The inclusion of other similar financial instruments depends on analytical requirements and data availability and quality considerations:

- Trade credit, i.e. credit granted directly by suppliers of goods and services to their customers is generally recognized as an important, short-term financing instrument for non-financial corporations. As trade credit is often provided by other non-financial corporations, it is more important for non-consolidated debt measures than for consolidated debt.

- The insurance liabilities of nonfinancial corporations under pension schemes for their employees in some countries represent large liabilities that are like other debt components in that they require predetermined, legally enforceable payments in the future.

- Financial derivatives are not included in the national accounts of governments and are not interpreted as part of the debt of non-financial corporations.

Traditionally, bank loans have been a major source of debt financing for most European companies. As the 2008 financial crisis has shown, European companies are more vulnerable when bank loans are limited. Therefore, a well-developed bond market can be an alternative source of financing for the real economy when credit shrinks (Giannetti, C., 2019). There is an in-depth analysis 


\section{Articles}

on this topic, prepared by experts from the European Central Bank. It argues that since the 2008 financial crisis, non-financial corporations in the euro area have responded to tight bank lending conditions by shifting the composition of their debt from bank loans to debt securities. At the same time, the price of market debt is rising along with the price of bank loans. The authors propose a model that can take these facts into account. They use it to assess the role of the debt structure in determining the response to investment activity and productivity (Di Fiore, F., Uhlig, H., 2015).

In Bulgaria, the situation is slightly different from that in Western Europe and the United States. Companies are rarely financed through corporate bonds (bond loans), which is a common practice in the West. Therefore, in Bulgaria the most significant share is the financing by banks and other creditors (suppliers, related companies and group companies, other liabilities), which can be classified as intercompany. This is the main reason why the research of corporate debt in Bulgaria and in other countries differs significantly in methodology and nature.

To the extent that bank lending stimulates the growth of the economy and the money supply and investment activity of companies, the internal financing is riskier because it leads to arrears, respectively deteriorated collection of receivables. The issue of intercompany liabilities is key in the present study and is given special attention. The most important definitions of corporate debt are made by G. Minassian (2013) in the publication of the Institute for Economic Research of BAS "Debt and macroeconomic imbalances". According to the author, the inter-company and intracompany financial relations are regulated by basic economic laws, the most important of which is the Commercial Law. However, not all violations of the law are registered and
Corporate Indebtedness of Non-Financial Corporations

in Bulgaria

sanctioned. As a result, unregulated and unauthorized obligations accumulate, which create tensions in the regular performance of the functions inherent in specific companies. The main factor for creating this type of debt is the incorrect behavior of companies, defaulting payers. G. Minassian concludes that "cultivating a culture of inter-company relationships is a process that requires a long time." Apart from being a consequence of misconduct, intercompany indebtedness must also be a "natural" phenomenon for the economy. This covers cases where one or another service provider - throughout the trade or production chain, has difficulties in its activities; or the cases in which the payers fall into insolvency and / or (consequently) and into insolvency. In the latter case, the relations between traders and / or producers are regulated by the Commercial Law (mainly), but in the first case - the relations are regulated in general by commercial law and in particular by the Law on Obligations and Contracts.

As can be seen from the above - in both cases, the development of financial relations is regulated by law. This, in turn, demonstrates the need for adequate legislative solutions, that governing intercompany indebtedness, to ensure that business units can function smoothly. It is logical to extrapolate to the following levels: meso- and macroeconomic. It is clear that the issues of the economic aspects of the operation of companies, placed in a legal context, represent a significant problem for theory and practice, but are "aside" from the research problem set here, and therefore will not be discussed. More and more details on them can be seen in a study by I. Beev (2017).

The ability to collect trade receivables in a timely manner is a key factor for the stability of companies' finances and their existence as business entities. To overcome the problem of overdue payments by customers, which is 
among the main problems faced by companies in Bulgaria, specific measures are needed on their part. But the difficulties in the realization of the production and the fear of deterioration of the relations with the clients hinder the fight against the overdue receivables (Taseva, G., 2016).

G. Minassian (2013) introduces the concept of a kind of intercompany multiplier, analogous to the monetary multiplier in the monetary sphere and explains it as the emergence of an intercompany indebtedness (especially if it is larger) arouses other intercompany obligations. The size of the intercompany multiplier depends on the degree of development of intersectoral interactions. The more specialized the economy, the more interconnected the various industries are in terms of mutual supply and performance, the higher it is and vice versa. This increases the role and responsibility of the regulatory suprafirm institutions at a higher level of economic development for ensuring a predictable and strict legal order of interconnections and interactions.

The financing of Bulgarian enterprises by indebtedness to suppliers, related enterprises, and enterprises of the group, as well as to other creditors and debtors is a common practice, especially important for providing the working capital of the companies. This is another argument in favor of the study of the so-called. in-house indebtedness in detail. Ultimately, maximizing the value of the company is established as a leading goal of their operation (Nenkov, D., 2016).

In connection with all that has been said so far, the financial, production or also called money cycle is the basis of indebtedness and deterioration of liquidity, because there is a period between the creation of the product (goods) and the receipt of payment for its delivery. The rapid clearing of naturally occurring intercompany liabilities is more than desirable and stimulates company activity (Hristozov, Y., 2014).

According to the recommendations of the European Commission (EU, (2017 / C 261/02) to Bulgaria "Debts of enterprises remain high (well above those of comparable countries), which burdens the balance sheets of companies and potentially limits the demand for credit and investment in the medium term" Corporate indebtedness in Bulgaria is becoming a major scourge for the development of enterprises and leads to difficulties in carrying out their main activity, often to insolvency and bankruptcy, and also creates a risk of reduced investment activity, lower revenues, reduced consumption, etc.

The European Commission's recommendations for 2018 (EC, 2018 / C $320 / 02)$ draw attention again to this problem: "The inefficiency of the insolvency legislation slows down the reduction of private sector indebtedness and the restructuring of nonperforming loans. The procedures are long, and the collection rate is low. Some elements necessary for a functioning legal framework are still missing, rules for the forgiveness of obligations and for giving entrepreneurs a second chance within a reasonable time after being declared bankrupt. The lack of data collection and appropriate monitoring tools does not allow an assessment of the effectiveness of either the old or the new procedures, including the restructuring of companies." For this reason, the next section will analyze these levels of indebtedness to draw key comments and conclusions.

\section{Analysis of corporate indebtedness in Bulgaria (2008-2018).}

Table 1 presents the number of companies participating in the survey. In 2008 they are about 200 thousand companies, and their number in 2018 is over 340 thousand companies. The number is important for 
determining the levels of absolute indicators

used on a company-by-company basis, which corresponds to the research thesis.

Table. 1. Count of enterprises participating in the statistical sample

\begin{tabular}{|c|c|c|c|c|c|c|c|c|c|c|c|}
\hline Year & $\mathbf{2 0 0 8}$ & $\mathbf{2 0 0 9}$ & $\mathbf{2 0 1 0}$ & $\mathbf{2 0 1 1}$ & $\mathbf{2 0 1 2}$ & $\mathbf{2 0 1 3}$ & $\mathbf{2 0 1 4}$ & $\mathbf{2 0 1 5}$ & $\mathbf{2 0 1 6}$ & $\mathbf{2 0 1 7}$ & $\mathbf{2 0 1 8}$ \\
\hline Count & 199846 & 229839 & 238744 & 250053 & 265609 & 278743 & 292099 & 306488 & 321863 & 328502 & 340829 \\
\hline
\end{tabular}

Source: NSI

The analysis of corporate indebtedness will be divided by several criteria, according to their maturity - general, short-term and long-term, according to creditors - financial institutions, suppliers, other creditors, etc., according to sectors to gain an overview and compare levels on indicators and on the basis of intercompany liabilities.

\subsection{According to the Debt Maturity}

In the period 2010-2018, several economists and experts, representatives of institutions (EC, BNB, BIA, BCCI) alerted about the high levels of corporate indebtedness in Bulgaria. Whether this is a fact will be sought in this part of the study. Level 18 shows the levels of the total debt of non-financial enterprises in Bulgaria for an 11-year period in billion leva and the average indebtedness of one enterprise.

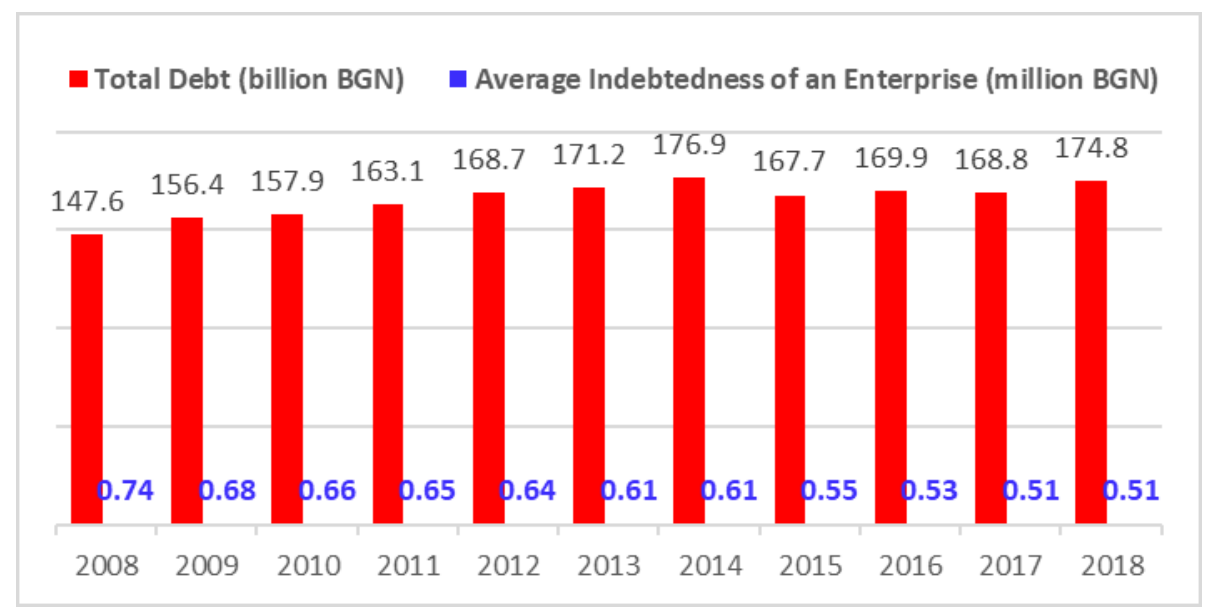

Figure 1. Total Debt of NFC in Bulgaria and average Indebtedness of one Enterprise Source: NSI, own Analysis

The total indebtedness of Bulgarian nonfinancial corporations in absolute nominal value is in the range between 147.6 billion leva and 176.9 billion leva, which is an increase of 32 billion leva. It is noteworthy that the value of total debt increases by each past year until 2014, when the highest values for the whole period are observed. Liabilities in 2014 amounted to 176.9 billion leva, and the growth compared to 2008 was about 30 billion leva.
The growth for 2014 compared to 2008 was 20 percentage points, and for 2018 compared to 2008 is 18.4 percentage points. In the next three years from 2015 to 2017 there will be a decrease of about 7-9 billion leva on an annual basis, but in the last 2018 the total liabilities will increase again to 175 billion leva, which is almost at the level of 2014. Sectors G. Trade; Repair of cars and motorcycles has the largest share of these liabilities - 40 billion 


\section{Articles}

leva, C. Manufacturing - 31 billion leva, $L$. Real estate operations - 27 billion leva and $F$. Construction - 19.5 billion leva. The liabilities of these four sectors accounts for nearly twothirds of all liabilities. The chart presents the average annual liabilities of a non-financial corporation. The values give a completely different type of information and it turns out that one enterprise was the most indebted in 2008 - it owes an average of 740 thousand leva, and the lowest indebtedness is in the last two years, in which it owes an average of 510 thousand leva. These results are a valid argument in favor of the research thesis, namely despite the growth in the absolute value of debt on the basis of all enterprises for the period (147.6 - 174.8 billion leva), then on the basis of average indebtedness of one enterprise things are on the contrary, there is a decrease (740-510 thousand leva).

In terms of their maturity, the changes in short-term and long-term liabilities as absolute levels and as a share of total indebtedness can be considered the data of the following figures 2 and 3.

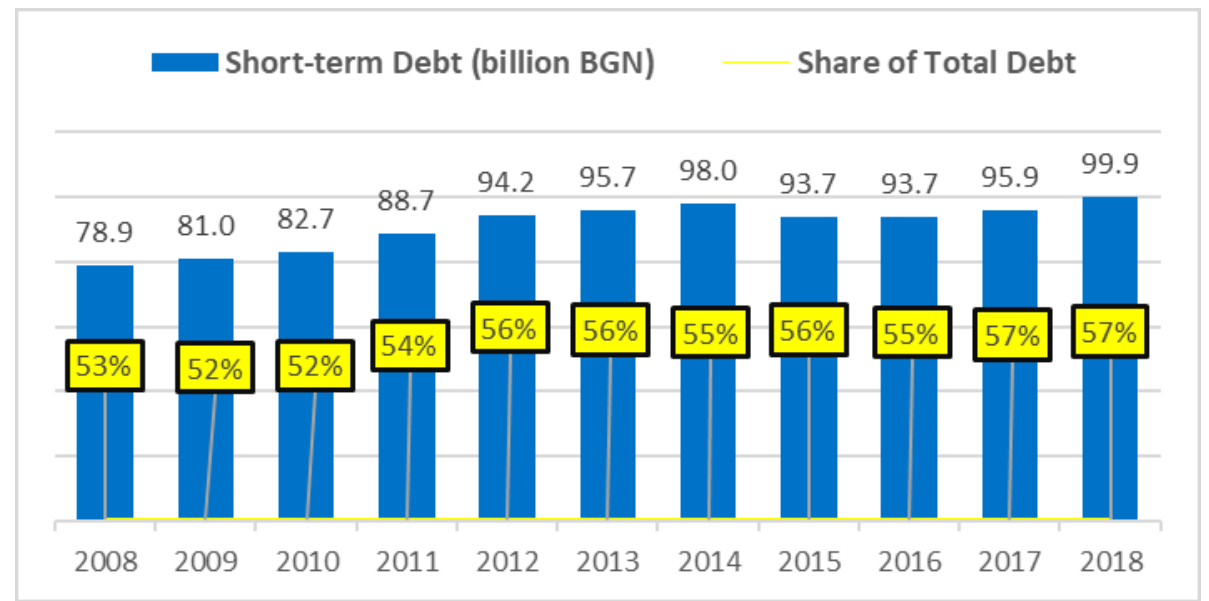

Figure 2. Short-term debt of NFC in Bulgaria

Source: NSI, own Analysis

The short-term liabilities of the company act as a free source of attracted capital. Shortterm liabilities range between 78.9 billion leva and 99.9 billion leva, with the lowest value in 2008 and the highest in 2018. Their value is also high in 2014 - 98 billion leva. The share of the total debt is observed as a percentage and it is the lowest in 2009-2010 and the highest in 2017-2018. The largest share of short-term liabilities from the sectors is again in sector G. Trade; Repair of motorcycles and cars - 27.2 billion leva, followed by sector $C$. Manufacturing - 20 billion leva and sector $F$. Construction - 12 billion leva. The amount of short-term debt depends directly on the frequency of payments on it. This allows to determine the level and the possibility to regulate the sources of funds during the management of this debt. Most often, shortterm liabilities are repaid by current assets - the resources used in daily activities. The growth of short-term liabilities for the 11year period is 26.6 percentage points, while the growth of current assets is close to 46 percentage points. for the same period. This exposes a far better liquidity of enterprises. The net working capital of enterprises in these 17 non-financial sectors is a positive value. It 


\section{Articles}

Corporate Indebtedness of Non-Financial Corporations

in Bulgaria

is noteworthy that short-term liabilities in each year have a higher share than long-term ones. However, measured based on one enterprise, the levels of short-term indebtedness again show that they increase only due to the increased number of enterprises participating in the statistical sample for each year.

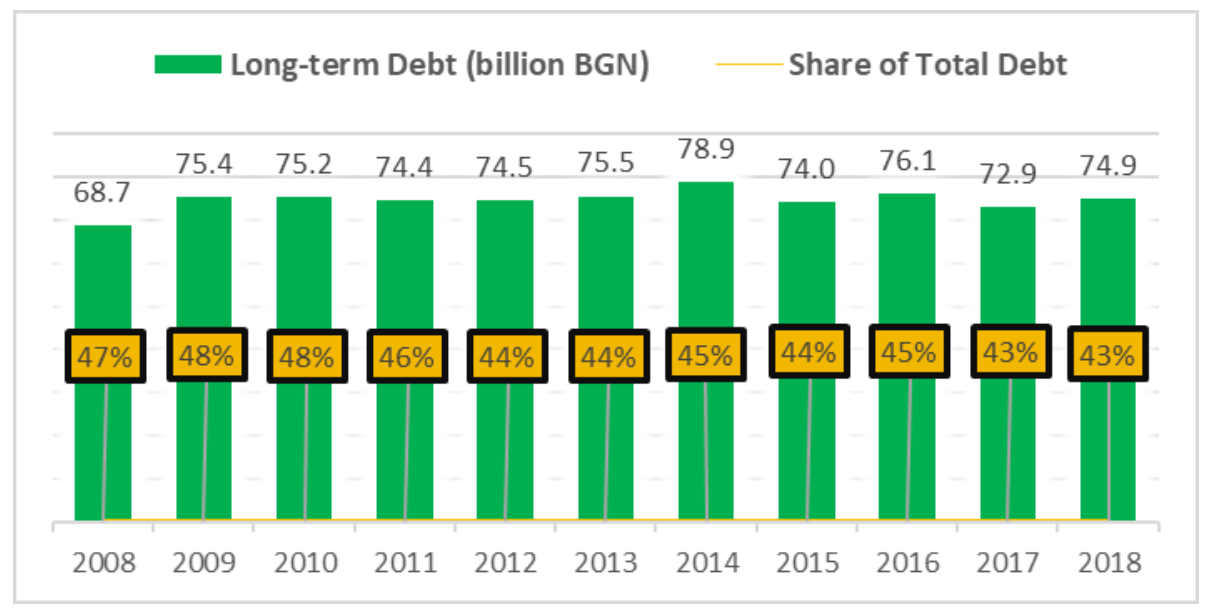

Figure 3. Long-term debt of NFC in Bulgaria

Source: NSI, own Analysis

Long-term liabilities are between 68.7 billion leva and 78.9 billion leva. Their highest value is again in 2014. As a share of total debt, they are between 43\% in 2018 and 48\% in 2009 and 2010 Long-term liabilities increased by 9 percentage points. for the entire studied period, the rate of which is lower than the growth of short-term liabilities - by 26.6 percentage points. The most significant change was registered in 2009 compared to 2008 , almost 10 percentage points. After 2014 , there is a decrease in their absolute values compared to the same 2014 .

It will be interesting to consider the absolute levels of indebtedness in enterprises by sector. This will presumably expose the differences in the scale of these sectors. The discrepancies in liabilities are mainly due to the number of enterprises that are part of these sectors.

\subsection{Indebtedness by non-financial Sectors and by economic Activities}

The idea in Figure 4 is to look at the levels of indebtedness of the non-financial sectors. The reason for the big differences is on the one hand the number of enterprises, on the other hand - the values of assets, sales revenues, in other words the scale of activity is different. The aim is to get an idea of which sectors are most indebted in terms of absolute levels of total debt, but it should be taken into consideration that it is much more accurate to measure the average indebtedness of one enterprise per sector for each year in order to assess whether the situation is improving or deteriorating. 
Articles



Figure 4. Total debt of the surveyed sectors (billion leva)

Source: NSI, own Analysis

It is evident that the lowest absolute nominal debt is observed in sectors $P$. Education, $S$. Other activities and $R$. Culture, sports and entertainment, and the highest are these values in sector G. Trade; Repair of motor vehicles and motorcycles, C. Manufacturing, L. Real estate activities and F. Construction. In sector $F$. the curve has downward trends in contrast to other sectors. It must be kept in mind that with each passing year, more and more enterprises are analyzed and included as part of the individual sectors. Also, a smaller number of enterprises participate in the sectors with the lowest total indebtedness than in the other sectors. In sector $J$. there is also a significant downward trend after 2015. The main purpose of the above chart is to show the sectoral conditionality and the difference in the scale of the enterprises included in them. Figure 4 aims to illustrate the summarized information in a comparative plan. Figure 5 presents the share of indebtedness by economic activities. 


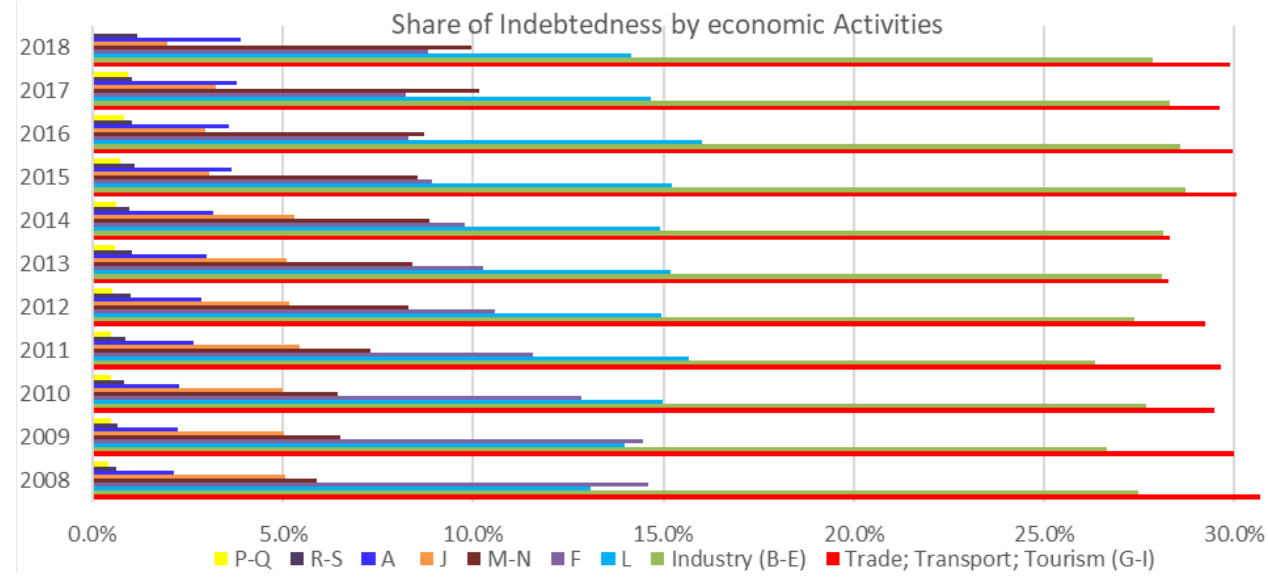

Figure 5. Share of total debt by economic activities in relation to the sum of liabilities of all sectors (\%) Source: NSI, own Analysis

The highest share is in the sectors of Trade, Transport and Tourism, around and above $30 \%$, followed by industry, which includes sectors $B, C, D, E$ between $26 \%$ and $28 \%$. Sector $L$ has a share of about $15 \%$. The other surveyed sectors have lower shares. The highest increase in this share for the period is reported in sectors $M-N$ (from $5.9 \%$ in 2008 to $10 \%$ in 2018), while the highest decrease in sector $F$ (from $14.6 \%$ in 2008 to $8.8 \%$ in 2018). The high levels of indebtedness in some sectors and the low ones in others are a result of the number of enterprises participating in the sample. It is typical for an economy that most of the enterprises are concentrated in the activities trade, transport, tourism, industry. Accordingly, the scale of assets, investments and sales revenues in these sectors is also higher. In comparison, it is typical for other economic activities related to the provision of services, which lack industrial and production character, to have low levels of indebtedness.

\subsection{Indebtedness according to the Creditor}

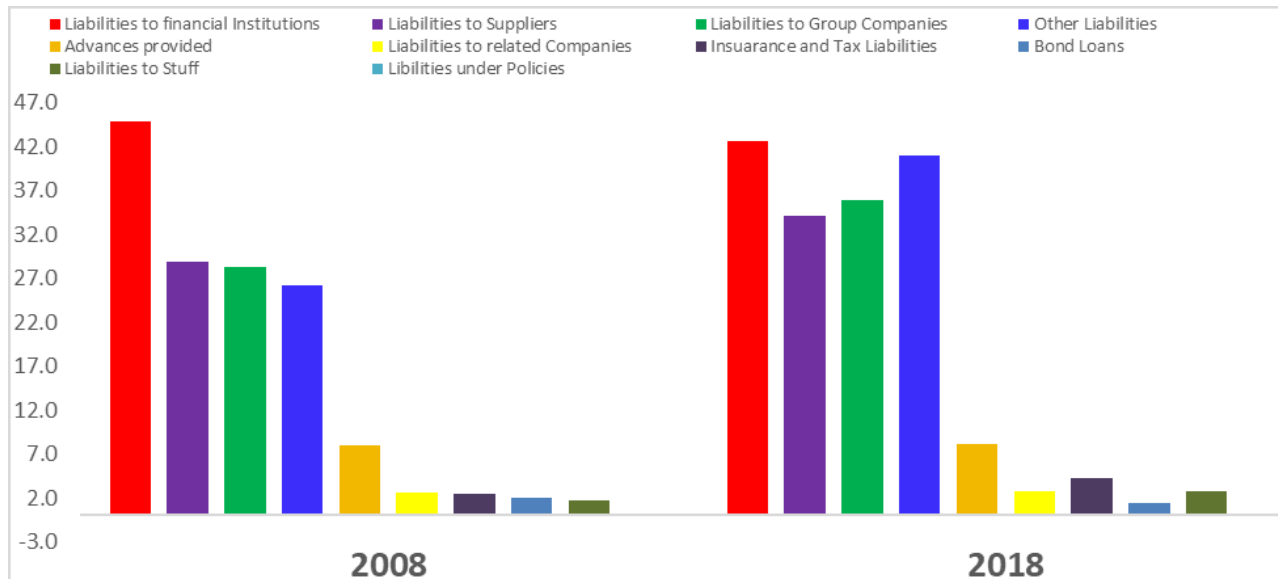

Figure 6. Liabilities of NFC according to the creditor for 2008 and 2018 (billion leva) Source: NSI, own Analysis 


\section{Articles}

In 2008, as in 2018, the highest share was occupied by liabilities to financial enterprises, which are interpreted mainly as borrowed capital by financial institutions. However, these liabilities decreased for this period from 44.9 to 42.7 billion leva, which is a decrease of 4.9 percentage points. Bank lending (including lending from other financial institutions; leasing; repo transactions) stimulates the investment activity of companies, increases the money supply, which is favorable for the economic development of the country, but in this case there is a decline in money demand through such type of lending. Receivables from banking institutions alone in 2008 amounted to 30.2 billion leva, while in 2018 they amounted to 32.9 billion leva (BNB, 2019). On table 2 can be traced the levels of loans received by non-financial corporations in Bulgaria.

Table 2. Loans to NFC in Bulgaria

\begin{tabular}{|l|c|c|c|c|c|c|c|c|c|c|c|}
\hline & $\mathbf{2 0 0 8}$ & $\mathbf{2 0 0 9}$ & $\mathbf{2 0 1 0}$ & $\mathbf{2 0 1 1}$ & $\mathbf{2 0 1 2}$ & $\mathbf{2 0 1 3}$ & $\mathbf{2 0 1 4}$ & $\mathbf{2 0 1 5}$ & $\mathbf{2 0 1 6}$ & $\mathbf{2 0 1 7}$ & $\mathbf{2 0 1 8}$ \\
\hline Count & 128677 & 126479 & 125227 & 125939 & 131485 & 131944 & 134289 & 133773 & 139231 & 148555 & 147495 \\
\hline Million leva & 30254 & 30937 & 31704 & 33431 & 35091 & 35135 & 31102 & 30614 & 30667 & 31199 & 32910 \\
\hline
\end{tabular}

Source: BNB

It turns out that the number of loans granted in 2008 was 128,677 , and in the last two years there has been a significant increase in the number of loans granted, reaching over 148,000 . On the other hand, the amount in 2008 was 30.2 billion leva, and in 2018 by about 2.7 billion leva higher - 32.9 billion leva. This is a slight increase against the background of growing net sales revenues, gross domestic product and economic growth. Low investment activity leads to weak demand for bank financing. A thorough analysis of the results shows that between 9.2 and 11 billion leva of the loans belong to sector $\mathrm{G}$., which is almost one third of all loans to non-financial corporations.

Due to the reasons mentioned so far, the companies resort to the so-called commercial lending. In 2008 the liabilities to suppliers are on the second position, and the liabilities to other debtors and creditors are on the fourth. In 2018, the two types of liabilities swap positions, and they are included in intercompany indebtedness, therefore they are dangerous and risky when their levels increase. The tendency that the liabilities to suppliers are on the fourth position in 2018 is positive, but their increase as an absolute value is a negative sign. Liabilities to suppliers amounted to 28.9 billion leva in 2008 and reached 34.2 billion leva in 2018 , which is an increase of 18.3 percentage points. The third position in the amount of liabilities is to enterprises in the group, which are also part of the intercompany indebtedness. In 2008 they are at levels of 28.4 billion leva, and in 2018 - 35.9 billion leva. Liabilities for advances are between 7.9 and 8.2 billion leva. Tax and social security liabilities also increased in the study period from 2.5 to 4.2 billion leva, which means that businesses owe more than 4 billion leva in outstanding liabilities to the state, but some of which are not due. Non-financial enterprises in the Bulgarian economy do not actively use bond loans as financing methods, which is why the corporate bond market in Bulgaria is not capitally developed. As can be seen in city 23 , the other types of creditors have a lower share, the lowest for policy obligations. Liabilities to affiliated enterprises, especially short-term ones, can be a signal for accounting concealment of turnover. However, their values have increased from 2.6 billion in 2008 to 3.3 


\section{Articles}

billion leva, which may be a worrying fact, but in 2018 they fell to 2.7 billion leva.

\subsection{Intercompany Indebtedness}

Intercompany indebtedness is a risk phenomenon above the natural ones for the financial relations and endangers the finances of the enterprises, putting them in a difficult position in repaying their obligations. High intercompany indebtedness often leads
Corporate Indebtedness of Non-Financial Corporations

in Bulgaria

to deteriorating liquidity and even insolvency. According to BIA (2014), the obligations between business entities (debtors and creditors) are conditionally considered as "inter-company", in which it is possible to set off "liabilities - receivables". These are liabilities to suppliers, group companies and associates and joint ventures, related companies, as well as bond loans, policies, advances and other liabilities.

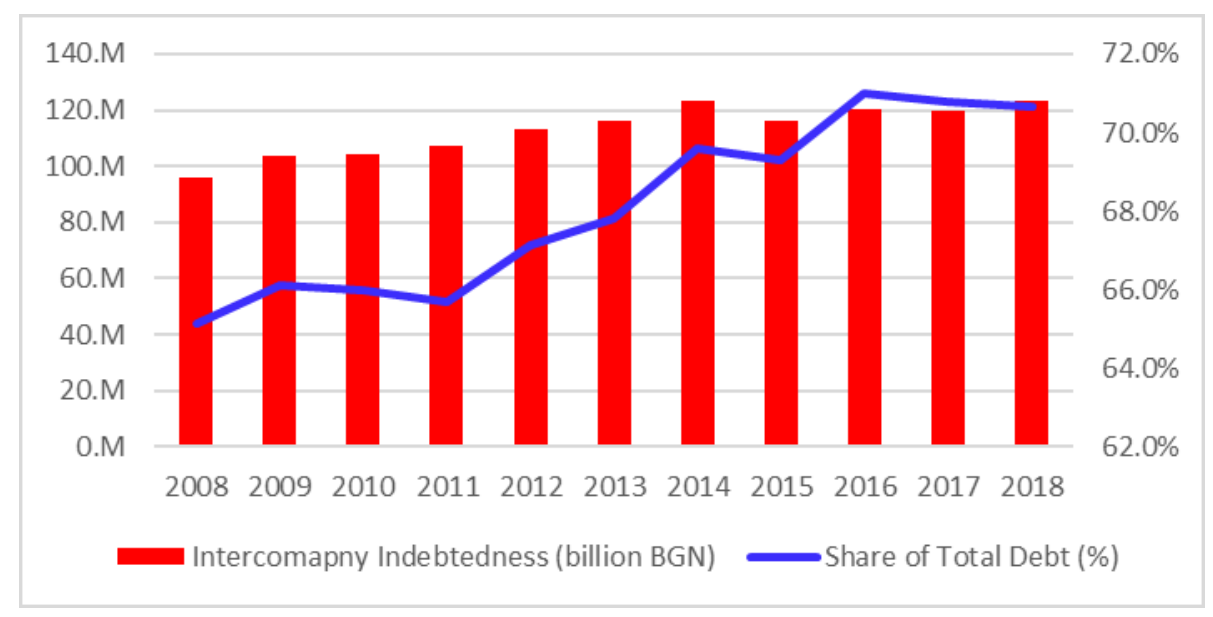

Figure 7. Amount of intercompany Liabilities (billion leva)

Source: NSI, own Analysis

Figure 7 shows the absolute amount of internal liabilities for the period 2008 - 2018. In the base year they amounted to 96.2 billion leva. Years of increase in their value followed, reaching a peak in 2014 - 123,1 billion leva and in 2018 - 123.5 billion leva. In the last year, their highest value was registered. The main part of the intercompany liabilities is formed by the liabilities to suppliers, the liabilities to group companies and the liabilities to other debtors and creditors. These three types of liabilities form over $80 \%$ of intercompany indebtedness. The trend line of figure 7 shows the share of domestic debt relative to total debt. The fact that the absolute values are growing is normal, due to the investment activity, the larger number of enterprises in the sample over the years, but the share increases from $65 \%$ to $71 \%$. This fact is also sufficiently indicative of the increased risk of default or non-payment of part of the obligations to these creditors. The overdue of the company's liabilities, respectively receivables, leads to deterioration of key financial indicators, such as: profitability, efficiency, liquidity, and in particular in the event of a negative change in sales revenue to a deterioration in the turnover of inventories and receivables, and an increase in the length of the financial and production cycle. However, if it is assumed that a large part of the induced receivables is mutual, i.e. one company owes a second, which owes a third, but the third owes the first the same amount of money, then the cleared intercompany indebtedness should be 


\section{Articles}

at much lower levels than shown in Figure 7. Table 3 shows the average annual intercompany indebtedness of one non-financial enterprise in thousand leva. A decrease compared to 2008 is observed in all subsequent years. The levels of the last two years are the lowest and generally decrease with each passing year compared to the base year. Thus, it can be concluded that the intercompany indebtedness, which falls on one enterprise, decreases with each following year and from 481 thousand leva in 2008 is 362 thousand leva in 2018, which is a good sign. to deal in part with this problem. The conclusion is that intercompany indebtedness is decreasing, and the crisis does not lead to an increase in the indicator.

Table 3. Average annual intercompany indebtedness of a non-financial enterprise (thousand leva)

\begin{tabular}{|c|c|c|c|c|c|c|c|c|c|c|}
\hline 2008 & 2009 & 2010 & 2011 & 2012 & 2013 & 2014 & 2015 & 2016 & 2017 & 2018 \\
\hline 481,2 & 449,8 & 436,3 & 428,5 & 426,6 & 416,3 & 421,5 & 379,2 & 374,6 & 363,7 & 362,3 \\
\hline
\end{tabular}

Source: NSI, own Analysis

\subsection{Relative indebtedness indicators}

The relative indicators, which seek a different view of indebtedness, allow a more accurate assessment of the changes, because the different number of companies included in the survey do not change the information to such an extent when it comes to ratios. The higher number of enterprises leads to an increase in absolute indicators, but in terms of ratios this is not mandatory. As in the first part, the analysis is based on five main indicators, two of which Debt to Equity and Financial autonomy ratio overlap to some extent because they are reciprocal to each other.

\section{- Debt to Equity (D/E) and Financial Autonomy Ratio (FAR)}

The debt to equity ratio and the reciprocal ratio for financial autonomy are key indicators of the financial independence of enterprises. Financial leverage in enterprises is a clear indicator of indebtedness and is a frequently used indicator in the analysis of individual enterprises. Figure 8 will present the levels of D / SC according to summary data for all non-financial sectors. The lower the D/E and the higher the FAR, the better the indicator for the finances of enterprises.

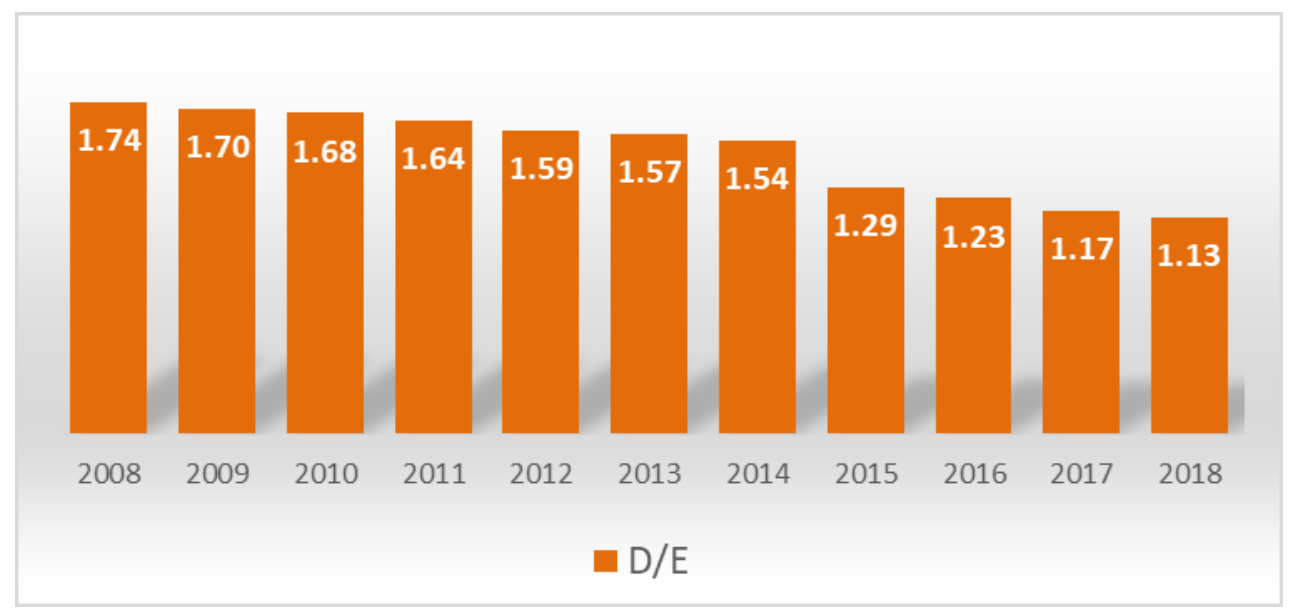

Figure 8. Debt to Equity Ratio

Source: NSI, own Analysis 


\section{Articles}

The ratio is used in making financial decisions and can consider possible risks in repaying liabilities. The debt to equity ratio of non-financial corporations is over one throughout the study period. This means that the value of debt exceeds the value of equity. The higher the ratio, the higher the risk of overindebtedness and insolvency. The improvement in the situation, which can be seen in Figure 8, occurs after the base year 2008, when the indicator decreased significantly and the best results in terms of risk were in the last two years. The results in the first 3 years are close. Sectors G. Trade; Repair of motorcycles and automobiles, J. Creation and dissemination of information and creative products; telecommunications and $L$. Real estate activities have the largest contribution to this high ratio. Only in these sectors the average value of the indicator for 11 years is over 2. In all other sectors it is below 1. This contradicts to some extent the theory, because in principle it is considered that high ratios are mainly heavy industry enterprises due to longer periods. of financial and production cycle. The coefficient $D / E$ above one speaks of over-indebtedness. However, the decline in the indicator has been significant in recent years and this is a very
Corporate Indebtedness of Non-Financial Corporations

in Bulgaria

good sign. Although the situation is improving, the values of the D/E indicator still alert to high indebtedness, which should not be ignored by companies and the state. To improve the situation, the indicator should acquire levels lower than 1, even lower. It is accepted in practice that equity exceeds debt. However, it should be noted that this declining leverage leads to lower risk to businesses because it reduces costs due to lower interest payments from debt reduction. The average size of all non-financial corporations for the whole period is 1.40 . If we adopt the methodology of S. Trifonova (2016), It turns out that nonfinancial enterprises in the Bulgarian economy have heavy financial indebtedness, because according to this methodology it is considered as such an indicator D/E over 0.75 . Even in this case, perhaps, there should be talk of excessive financial indebtedness. It should also be borne in mind that the indicator is mostly applicable to an individual enterprise, and in the case of consolidated data, information may be distorted. The following chart examines the financial autonomy of non-financial corporations in Bulgaria. There is an upward trend of the indicator, which is a positive sign.

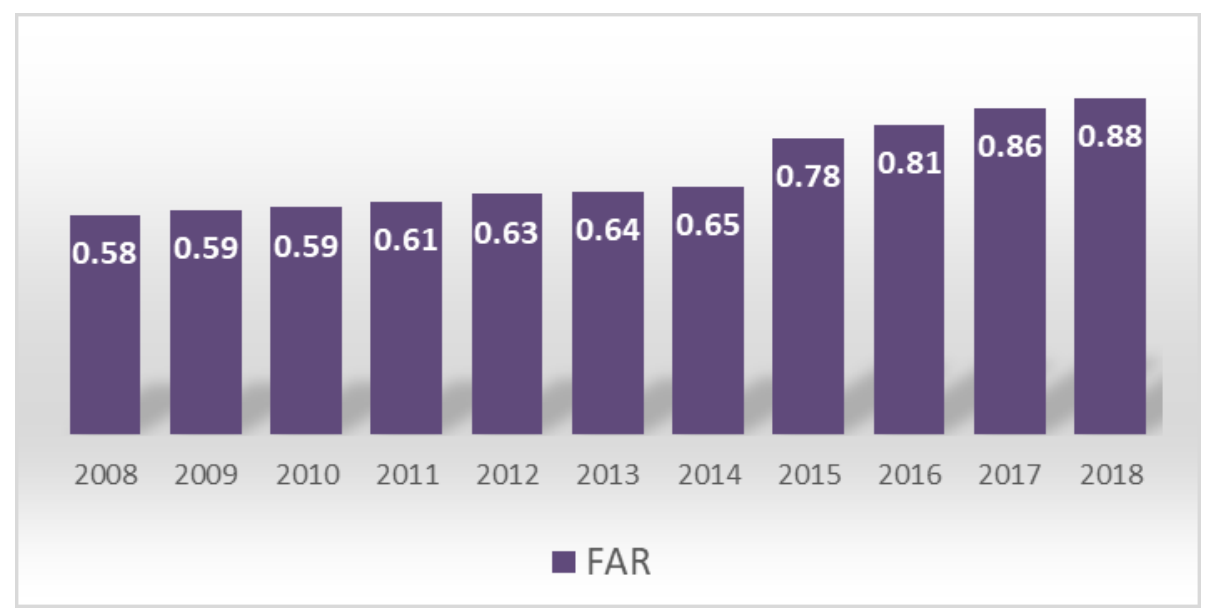

Figure 9. Financial Autonomy Ratio

Source: NSI, own Analysis 


\section{Articles}

The coefficient for financial autonomy is inversely proportional to the $\mathrm{D} / \mathrm{E}$, therefore values above 1 are accepted as acceptable. That is, all values for this indicator will be below 1 , because for D/E they are above. Along with the improving situation in figure 8 , the data in figure 9 will also improve in this direction. The last 4 years stand out as the best. The improvement is due not so much to liabilities, which grow in absolute value after 2014, but rather to higher values of companies' equity. For comparison, the change in liabilities for 2018 compared to 2008 is 18.4 percentage points, while the equity for the same period is 81.4 percentage points. The difference is very significant, and the conclusion is that non-financial corporations significantly increase their own financing at the expense of borrowed capital.

\section{- Debt to Assets Ratio and Long-term Debt to Assets Ratio}

The other leverage ratio that is essential is the debt-to-asset ratio, which is a measure of a company's assets that are financed by debt rather than equity. In this case, the levels of long-term debt to assets are considered, which is an estimate representing the percentage of the corporation's assets financed by loans or other liabilities lasting more than one year. This ratio is a general measure of the longterm financial condition of a company and this distinguishes it from D/A. The levels of the indicator's D/A and LTD/A can be traced in Figure 10.

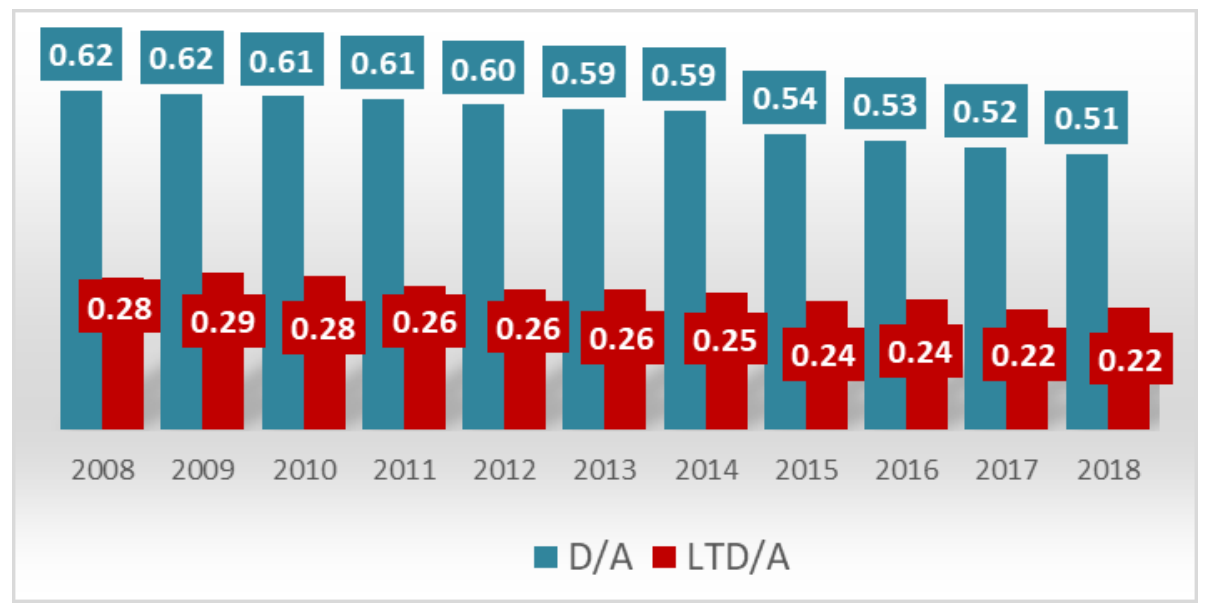

Figure 10. Debt to Assets and Long-term Debt to Assets Ratio

Source: NSI, own Analysis

The ratio provides information about how much of the assets are financed by debt rather than equity. Shows how non-financial corporations acquire more assets over the years. Through D/A investors, respectively creditors assess whether companies have sufficient funds to cover liabilities and whether they can achieve a return on investment. The lower the value of the indicator, the lower the risk for enterprises. From the data in Figure 10 , it can be concluded that the situation is improving with each passing year, both based on total debt and based on long-term debt. The lower level of financial leverage in recent years means that companies are gaining a higher degree of financial flexibility. Conversely, higher leverage in the early years would give conflicting signals to creditors. 


\section{Articles}

The highest indicators are registered in sector F. Construction and sector $L$. Real estate activities. Firms with a high degree of financial leverage will find it more difficult to remain financially stable during a recession than with a low level of leverage. The average value for all sectors on an 11-year basis is 0.58 . The disadvantage is the fact that the quality of the assets of all non-financial corporations cannot be assessed. The long-term ratio is the assets of enterprises financed by liabilities over 1 year. Demonstrates the ability of enterprises to meet the financial requirements for outstanding loans. The decline, which is registered in the ratio between the long-term debt and the total amount of assets of city
Corporate Indebtedness of Non-Financial Corporations

in Bulgaria

25 , means that the companies are gradually becoming less dependent on debt to develop their business. Non-financial enterprises have a long-term debt of 0.29 leva for every one lev invested in assets, and in 2018 it is 0.22 leva. The average value of the LTD/A ratio for nonfinancial enterprises based on the 11-year period is 0.26 .

\section{- Interest Coverage Ratio}

The ICR ratio shows the coverage of interest rates relative to the company's gross profit. The higher it is, the greater the ability of companies to service interest on their debt. Figure 11 clearly shows the changes over the years.

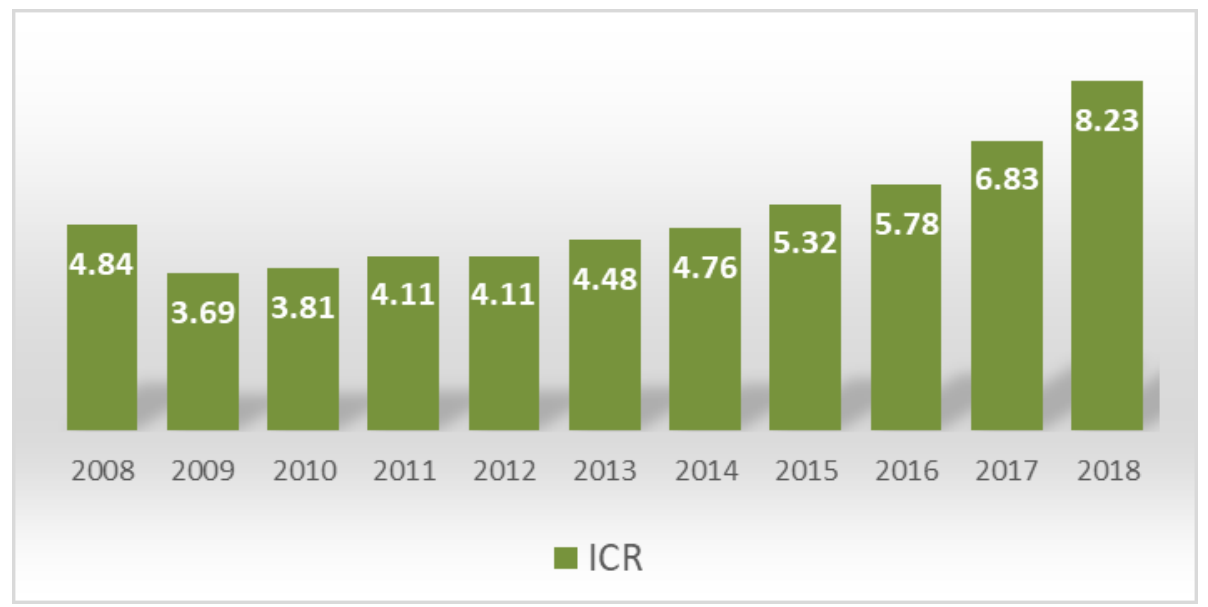

Figure 11. Interest Coverage Ratio

Source: NSI, own Analysis

The ratio gives an idea of indebtedness and is used to determine the ability of an enterprise to pay interest on outstanding debt. The ability of a company to meet its interest obligations is an aspect of the company's solvency and is therefore a very important factor for shareholder returns. After 2008, the indicator deteriorated due to the decrease in the gross profit from nearly 18 billion in 2008 to 13-15 billion leva in the next 3-4 years, plus the increase in the value of interest liabilities. In this case, it is assumed that the financial and economic crisis has a negative impact on profits and the ratio. The indicator has improved significantly over the last 3-4 years and is like other relative indicators. The highest value is in 2018, in which the gross profit of non-financial corporations covers almost 6 times the interest on loans. In the same year, the gross profit amounted to 25.4 billion leva, while the interest liabilities amounted to 4.4 billion leva. However, it 


\section{Articles}

should be borne in mind that sometimes companies pay only interest and renegotiate the payment of principal for a later date. stage. The ratio provides information on the short-term financial condition of non-financial corporations rather than on the long-term one.

\subsection{Corporate Debt in relation to other key indicators}

The third point of view that will be presented is related to the comparison of corporate indebtedness in Bulgaria with other key macro- and microeconomic indicators. The idea is to track trends and relationships between liabilities, the country's gross domestic product, investments and sales revenues of non-financial corporations. This will allow for additional comments regarding the indebtedness and to look for a new moment in connection with the conclusion of the main conclusions and recommendations. The moment is new, because company indicators will be correlated, i.e. microeconomic to macroeconomic indicators. In this way, a link is sought between corporate indebtedness, which depends mainly on company policies, and other indicators that are outside company policies (excluding sales revenue).

\section{- Liabilities and gross domestic product}

Gross domestic product is a generally accepted indicator of the economic development of a country, and its dynamics is the basis for assessing economic policy in view of the tasks set for macro policy makers. GDP is also a summary indicator of the condition of business units, and the trends of its change are decisive for them. This explains why a common practice in estimating indebtedness is to compare it with GDP. Based on own calculations, resp. and according to the available information, Figure 12 shows the specific values of the ratio, and the corresponding time series is presented (data by years):

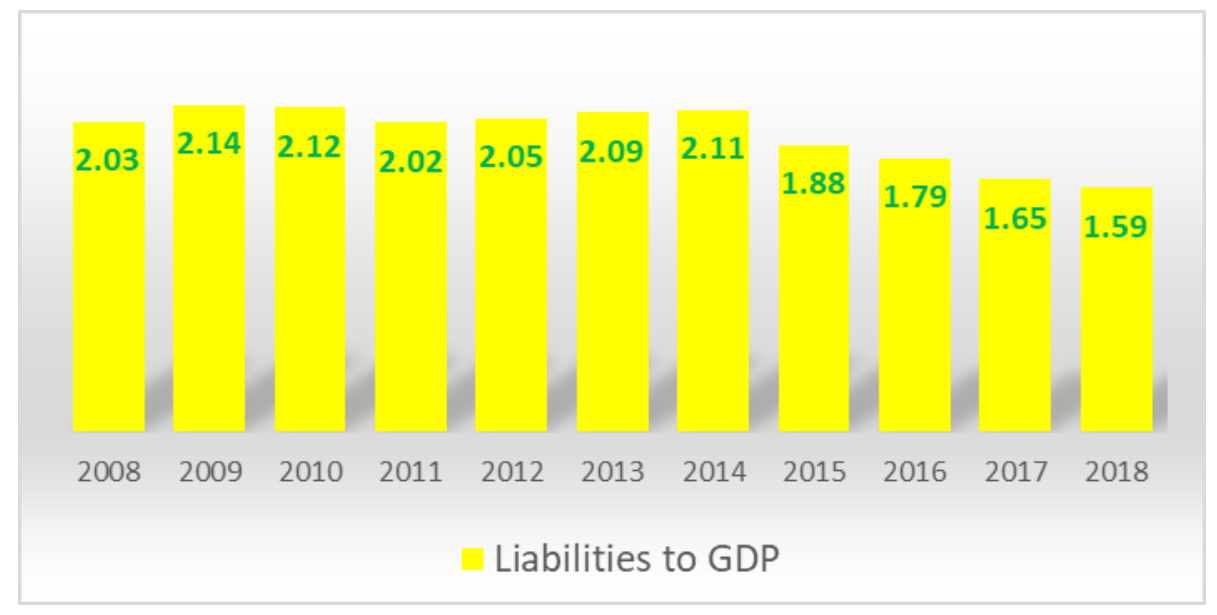

Figure 12. Liabilities of NFC to GDP

Source: NSI, own Analysis

GDP is accepted as a standard in the result of the economic activity of measuring the national economy and can be calculated by the production method, the value method and the end-use method. In all three methods, the goal is to measure each farm. In this case, data on GDP by production methods are used. The lower the results of this ratio, the better sign it is of financial independence from debt and for 


\section{Articles}

the economy. However, it should be borne in mind that in this case only the liabilities of non-financial corporations are monitored. To get a complete picture, the obligations of households should be added, the so-called total indebtedness (Yankov, I., 2016), but this is not the subject of the current study. In 2008 , liabilities were $203 \%$ of GDP, measured in nominal terms, at current prices. These levels increased in the years of crisis to $212-214 \%$, but in 2011 decreased to $202 \%$. After 2016, there is a significant decline, and in 2018 liabilities are $159 \%$ of GDP. This is a pretty good result for the economy and indicative of a reduced share of debt to GDP. This is due to the significant growth of GDP at a faster pace than the growth of the total debt of non-financial corporations. GDP grows by 50.6 percentage points. for 11 years, while the liabilities by only 18.4 percentage points. Thus, GDP growth is significantly ahead of debt growth. This determines the decrease in the ratio and its
Corporate Indebtedness of Non-Financial Corporations

in Bulgaria

better values in recent years. In other words, in 2008- 1.03 leva of debt fell to 1 lev of GDP, while in 2018 the result is 1.59 leva. The positive trends for GDP growth in the coming years give grounds to forecast and are an important prerequisite for improving the financial situation and reducing the levels of corporate indebtedness. Despite the improved situation, debt-to-GDP levels are high, but as the economy grows, they will continue to improve.

\section{- Liabilities and investments}

The costs of acquisition of tangible fixed assets are indicators characterizing the investment activity of enterprises in all sectors of the economy. (NSI, www.nsi.bg). For this reason, the cost of acquiring fixed assets is considered an investment. The data refer to the activity of the enterprises, which have incurred expenses for acquisition of fixed assets and acquired fixed assets on the territory of the country.

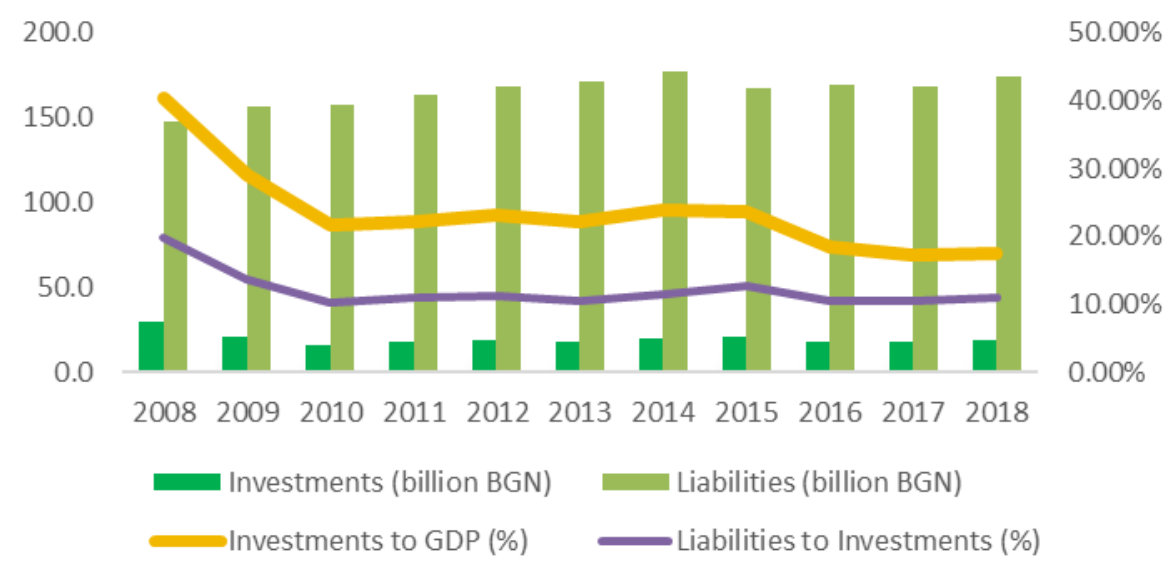

Figure 13. Investments of NFC and GDP

Source: NSI, own Analysis

The reason for the study of the indicator is the statement about the existence of $a$ strong influence with inverse dependence of the debt burden on the investment activity, which in this case is proved. Figure 13 shows that as debt increases, investment decreases. The highest investment activity was in 2008 - 29.4 billion leva. A special 


\section{Articles}

decline was observed in the crisis years 2010-2011 to 16.2 billion leva, in 2015 the costs for tangible fixed assets marked again growth to over 20 billion leva. In the last three years, investments have decreased again, amounting to 19.2 billion leva in 2018 . Despite the highest levels of liabilities in 2014 and 2018, investment growth is insignificant. compared to previous years. With the lowest indebtedness in 2008, the highest investment activity was observed. Investments relative to GDP decreased during the study period. The lowest value of this ratio is below $20 \%$ in the last three years. The reason is again in the significant growth of GDP in recent years, and not so much in the decline in investment. The ratio of investments to liabilities is declining, which indicates an improvement in the indicator. For every lev investment at the beginning there is a debt of 5 leva, and at the end of the period a debt of 9 leva. Measured investments in debt are declining, which is a bad signal for the activity of companies to invest. If, due to asymmetric information, creditors cannot distinguish between "good" and "bad" borrowers, there will be a rationing of capital, where the cost of loans will be higher, and investments will be lower than optimal with complete information. Again, if the company has less internal funding, its investments will be more limited. External loans are at a higher price than domestic funds and due to the intermediary and crisis costs of debt, which increase with the degree of indebtedness. But external loans are preferable in terms of risks to the economy and companies and stimulating them at a better price would increase investment activity. When the access to external financing is limited and expensive, investments are influenced by the cash flows generated by the company. This dependence is also observed in Bulgarian companies and is especially pronounced in the years after the financial and economic crisis. Thus, the sensitivity of investments to internal financing can be a useful indicator for access to finance and the functioning of the financial system. If companies make their investment decisions, not limited to their own financial resources, there will be evidence of a relatively efficient distribution of capital in the economy.

\section{- Liabilities and net Sales Revenues}

The increase in the value of net sales revenues of non-financial corporations can be used as a key indicator for the growth of business and the economy. Net sales revenues include sales of goods and services that provide the clearest and most difficult to manipulate information about the real financial situation. It is for this reason that in a large part of the financial indicators such as those for profitability and turnover, the net sales revenues are taken, and not all revenues. Some studies on indebtedness, such as that of BIA and others, use total revenues, but in my opinion, this distorts the information, because total revenues include interest income, which is often between related companies and group companies, ie. they are not real income and are rarely paid. Figure 14 shows the relationship between net sales revenues and liabilities of non-financial corporations in Bulgaria. 


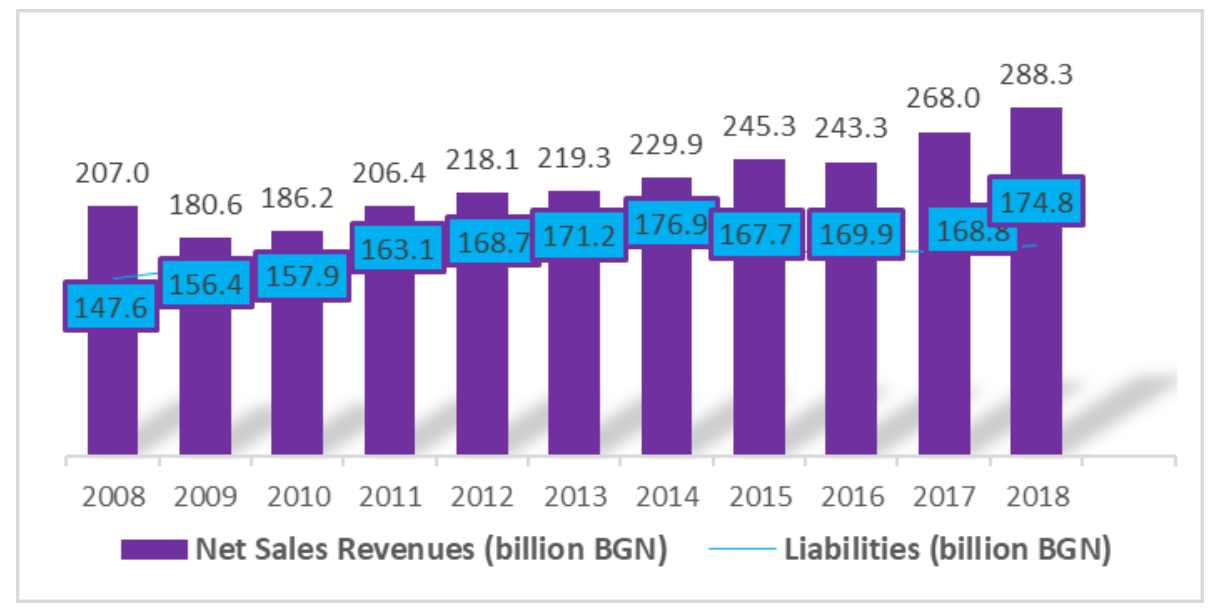

Figure 14. Net Sales Revenues and Liabilities of NFC in Bulgaria

Source: NSI, own Analysis

Net sales revenues amounted to 207 billion leva in 2008. The financial and economic crisis had a significant impact on them, as they decreased to 180 and 186 billion leva in 2009 and 2010, and in 2011 they reached the levels of 2008. In the following years there is an increase, as in 2015 their value was 245 billion leva, and the highest was in 2018 - 288 billion leva. The change compared to 2008 is 39 percentage points. The change in liabilities, as already mentioned, is only plus 18.5 percentage points. In this chart, the relationship between net sales revenue and liabilities can be clearly seen. For example, in 2018, when the net sales revenue increases, the liabilities also increase significantly. But this is not the case in all the years studied. In 2009, liabilities decreased despite the significant decrease in sales revenues, this is due to the momentum before the crisis

and the speed that companies have gained, without yet realizing the real economic and financial situation in the country. Another such example is 2015 . In other years, both indicators are moving in the same direction. Figure 15 compares the liabilities to net sales revenues. Throughout the period the values are below 1 , which is a good indicator. The lower the data, the better the indicator of the financial condition of non-financial corporations. The increase in net sales revenue is an indicator of sustainable business growth and helps to some extent to reduce the risks of high indebtedness. The reasons for their increase are due on the one hand in the larger number of enterprises in the sample, on the other hand in the growth of the economy and the value of assets and capital that enterprises use to realize these revenues.

Economic Alternatives, Issue 4, 2020 


\section{Articles}

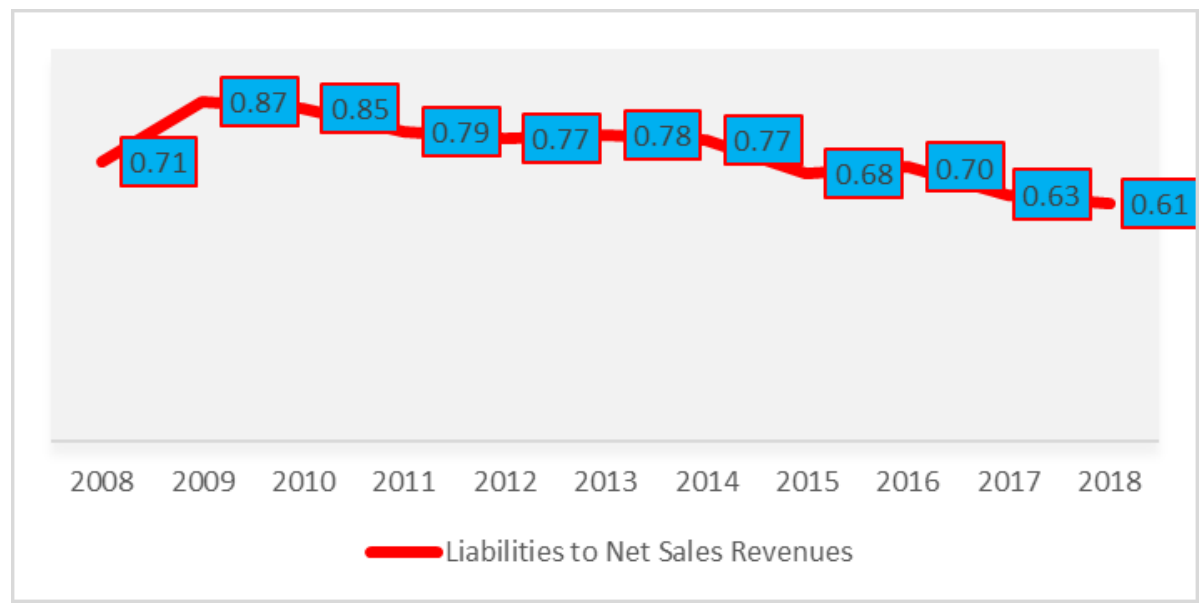

Figure 15. Liabilities to net Sales Revenues of NFC in Bulgaria

Source: NSI, own Analysis

As can be seen from the results obtained, the highest ratio is before 2009 and 2010 0.87 and 0.85 , respectively, and the lowest in the last two years - 0.63 and 0.61 . They are also the best in terms of this indicator. This fact is mainly due to the increased net sales revenues. Between 2009 and 2014 the situation is riskier, and the finances of enterprises are more unstable. The situation is improving for the following reason: in 2008 1.40 leva net sales revenues fell to $1 \mathrm{lev}$, while in 2018 they fell to almost 1.65 leva. In other words, the growth rate of net sales revenue during the period under review is higher than that of liabilities. If this trend continues in the coming years, it will help reduce corporate debt.

\section{- Liabilities and Receivables}

As an element of the financial structure in the assessment of corporate indebtedness, it is good to make a comparison with receivables, but this point is often omitted in the analyzes. This analysis is important because the outstanding obligation of the borrower is a receivable for the creditor, ie. higher levels of receivables than liabilities indicate an improvement in the situation, as they will represent a higher share of liabilities. A good example in this regard are the analyzes of the Bulgarian Industrial Association (BIA, 2014) and the Institute for Economic Research (Yankov, I., 2014). The latest study mentions the indicator of net corporate indebtedness, which represents the difference between aggregate receivables and aggregate ratios and is compared to GDP. According to the author of the above study, it can be assumed that the simultaneous increase in liabilities and receivables is a function of economic growth and financial flows in companies (Yankov, I., 2014). This statement is controversial, because on the one hand it can be a positive moment for the indebtedness, but a negative one for the solvency, i.e. depends on the viewpoint. Figure 16 shows the levels of liabilities, receivables and the ratio of receivables to liabilities. 


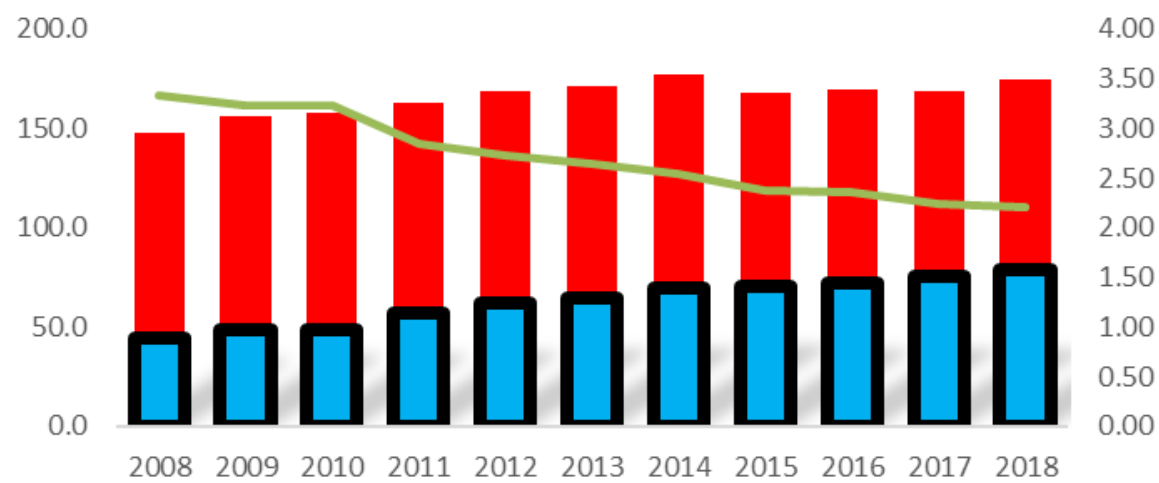

Liabilities (billion BGN)

Receivables (billion BGN) Liabilities to Receivables

Figure 16. Values and ratio of Receivables and Liabilities of NFC Source: NSI, own Analysis

The chart shows what part of the liabilities are receivables. Unlike the liabilities, the receivables increase in each following year and the change in them is plus 79 percentage points. for the studied period compared to the base year, while for liabilities it is plus 18.5 percentage points, as already noted. Receivables amount to 44 billion leva in 2008 and reach levels of 79 billion leva in 2018 . It is more important to follow the line of the ratio presented in the chart. The share of receivables compared to the liabilities of nonfinancial corporations is increasing, the trend is upward. In 2008, 0.30 leva receivables fall on each lev, while in 2018 it is 0.45 leva. That is, if we look at it from the point of view of indebtedness, most receivables should lead to more liabilities, which however, they will be covered when the receivables are repaid. The following facts should be noted: first, it is not known what part of these receivables is overdue and most of them may be due at the date of publication of the financial statements; second, the practice of overdue debt and bad debts is dangerous and can be fatal for some companies. Therefore, companies should be careful about their receivables and take all preventive and follow-up measures so as not to put their finances at risk. The management of receivables and their turnover is a key element of corporate financial management. Reducing their turnover in days will favor the solvency of companies.

\subsection{Analysis of the obtained Results}

The main and significant conclusion from the analysis of the sectors is that there is a sectoral (sectoral) conditionality and each sector has different levels of absolute and relative indebtedness. The data on absolute indebtedness should not be seen only as final values, because the number of enterprises included in the sectors differs significantly. To make a real comparison, it is important to measure the average indebtedness of an enterprise for the whole period. According to summarized data for all sectors, the total indebtedness is the highest as an absolute amount in 2014 and 2018, respectively 176.9 and 174.8 billion leva. The lowest values are registered in 2008 - 147.6 billion leva. Unlike public debt, corporate debt is growing, which negatives on the economy and the real sector. If the indicator average total indebtedness of one enterprise by years is used, it turns out that the highest indebtedness of one 


\section{Articles}

enterprise in 2008 is 740 thousand leva, and the lowest in 2018 is 510 thousand leva. The results per enterprise are just the opposite of the total absolute indebtedness data per all enterprises included. This is a clear sign that the situation with company liabilities has been improving in recent years. The total amount of debt depends on the activity of the enterprise on the market. The more active the production, the higher the realization. As a result, the amount of forthcoming costs will also increase. This in turn will create conditions for attracting additional funds. An increase in the share of short-term liabilities and a decrease in long-term liabilities is a bad sign for the ability of companies to repay their current debt. The total volume of loans affects the length of the company's financial cycle. In particular, the short-term liabilities of the organization adjust the amount of capital needed to replenish current assets.

High intercompany indebtedness is a dangerous phenomenon because it can lead some companies to a disrupted supply chain, and to those affected by insolvency and bankruptcy, which in turn can cause a chain reaction and lead to a recession. It is considered risky and creates preconditions for the blocking of company finances, deterioration of profitability and liquidity and difficult access to attracted capital. The situation is as follows: the highest values are again in 2014 and in 2018 - about 123 billion leva, and the lowest in 2008 - 96 billion leva. If we measure the intercompany indebtedness, which falls on one enterprise, the exact opposite results are obtained, the intracompany indebtedness is in 2008 481 thousand leva, and the lowest in 2018 - 362, 35 thousand leva. This moment can be considered as a significant contribution of the survey, because in other analyzes the number of companies included in the sample was not considered. A very important detail in the analysis of liabilities, which is often overlooked as well, is that there is no way to study what the agreements between the companies are, whether there are double set-offs of receivables and payables, which to some extent distorts the final results. For example, one company owes another amount of money and the third company owes the first. The obligation is three times the amount, but it is only once this amount. Therefore, it is difficult to establish at $100 \%$ the true levels of intercompany liabilities. For this reason, the current analysis seeks different perspectives to obtain more comprehensive information. Regarding the factors, the complicated procedures for bank lending, high interest rates and fees lead to lower demand for this type of financing, which undoubtedly increases the value of commercial lending and worsens the situation with intercompany debt and this was clearly demonstrated in the analysis. A negative effect of the initial induction of contingent liabilities is the reduction of the velocity of money circulation, respectively the increase in money in circulation, other things being equal. Businesses are stressed by the thought of bad debts that they would reinvest in their working capital. For this reason, they are often forced to have more money to deal with liquidity problems, which leads to the freezing of money in the form of assets and their non-investment at some point will worsen their profitability.

The banking system is a major source of fresh finance for non-financial corporations. Unlike liabilities to other creditors, which are a consequence of forced or unforced actions of the counterparties, the agreed loans are the result of a conscious mutual transaction. Lending faces several challenges, mainly related to the stress on credit institutions after the financial and economic crisis, the search for better collateral and the careful study of borrowers. Although as a share bank lending 


\section{Articles}

decreased (from $30.4 \%$ to $24.4 \%$ of the total debt for the period under review), it occupies a significant part of corporate financing. To balance their financial condition, Bulgarian non-financial corporations rely heavily on bank lending, overdue liabilities to suppliers, other debtors and creditors and to group companies (Figure 6). Given that the latter three are part of intercompany indebtedness, bank lending accounts for a significant share of total indebtedness and still allows banks to put pressure on businesses by imposing various types of fees such as penalties, to review conditions, to renegotiate. or refinancing loans. Against the background of declining liabilities to financial institutions, the already mentioned liabilities to suppliers (from 28.9 to 34.2 billion leva), to group companies (from 28.4 to 35.9 billion leva) and to other debtors and creditors (from 26.1 to 41 billion leva). These data are key to the analysis and prove that Bulgarian non-financial corporations rely heavily on commercial lending. The advantages of financing the assets with debt capital are expressed in the tax benefit that the cost of financing brings, as the interest on the debt is recognized as an expense of the business and thus the taxable profit of the company is reduced (if any). The fact that in case of insolvency of the company the owners of the company are satisfied last, is reflected in the higher price of the own capital. In general, companies with more stable and predictable cash flows have a higher capacity to attract and service debt capital, as well as those companies whose balance sheets are dominated by liquid assets.

In terms of relative indicators based on aggregated data, the situation is improving. The D/E ratio drops from 1.74 to 1.13 but is still above 1. This shows that Bulgarian enterprises are no less decapitalized. Accordingly, the FAR increases from 0.58 to 0.88 , which indicates higher financial
Corporate Indebtedness of Non-Financial Corporations

in Bulgaria

independence from debt, but still the results remain below 1. D/A falls 0.62 to 0.51 , and LTD/A from 0.28 at 0.22 . The ICR increases from 4.84 to 8.23 , so gross profit significantly exceeds the amount of interest. The obtained results and the reduction of the risk compared to the possibility for non-fulfillment of the obligations decrease, which was proved by the analysis of the absolute values, when the indebtedness of a company is measured. An important point in the assessment of relative indicators is that they provide a different type of information about the indebtedness of enterprises and allow additional analysis of the data. They are even more suitable for estimating indebtedness because the change in the number of sampled companies does not change as significantly as in absolute terms.

Increasing indebtedness is not so dangerous in itself when it is accompanied by an increase in GDP, net sales revenues and the amount of investment, because it compensates for this negative and dangerous phenomenon for businesses and the economy. It is for this reason that in the second chapter an attempt is made to compare the changes in these indicators and the indebtedness. Liabilities to GDP decreased from 2.03 to 1.59 for the period under review, which is a positive result in terms of risk. The main reason for this was pointed out, namely that GDP is growing significantly. On the other hand, the investment activity in the country decreases, especially compared to 2008 . The decrease for the studied period is nearly 10 billion leva. 17\%. These data are worrying for the Bulgarian economy and speak of a deterioration of the investment environment and a significant outflow of investments. Throughout the period, the positive ratio between liabilities and net sales revenues is maintained, i.e. revenues exceed the liabilities of companies. The best values are in 2018 0.61 , and the reason for this is the high growth 


\section{Articles}

of net sales revenues - 283.3 billion leva and liabilities of 174.8 billion leva. This proves the statement of G. Minasyan (2013) that lending is a bilateral contractual process that inevitably correlates with the degree of indebtedness. It is equally true to say that commercial banks are shrinking lending, and that companies are reluctant to invest. However, as practice shows and the theory summarizes, the priority is demand. The intersection is the price of the loan, in which all elements of the market are focused. The assessment of indebtedness should be made from the point of view of the achievement of the result, and not simply from the positions of the indebted subjects. There is no absolute criterion for assessing the degree of indebtedness - it is high or low not in accordance with some abstractly formulated levels, but according to their contribution to the achievement of final positive results. These results are commensurate with the growth rates of investment and economic activity, respectively with the growth rates of GDP.

Receivables in 2008 amounted to 44.2 billion leva and in relation to intercompany indebtedness the result was 0.46 , while in 2018 receivables amounted to 79 billion leva and their ratio to intercompany liabilities was 0.63. The fact that this indicator is increasing is a clear sign that the companies may be indebted to some extent due to uncollected receivables and thus compensate for their deteriorating liquidity. This question was commented by I. Yankov (2014). Most often, the receivables of companies from other companies are related to delayed or deferred payments for supplies, and as for the state and municipalities are public procurement, tenders and non-refundable taxes. This phenomenon for the EU can lead to turbulence, which puts companies in a state of increased need for financing, which can be done by delaying and overdue payments to suppliers, related companies, group companies, staff and others. With the synchronous growth of receivables and payables, it can be assumed that the total indebtedness is mainly a function of the growth of the economy and the financial flows of the companies themselves. The government concludes contracts with individual companies and concludes contracts under the Public Procurement Act, which provide for deadlines for implementation and payments. Often these deadlines are not met by both parties. This delay in payments occurs with both central government and local government. For example: The financial and economic crisis is drastically changing the situation. At the end of the first quarter of 2009 the overdue government liabilities were estimated at 89 million leva, and at the end of the year they reached 799 million leva. of $7 \%$ of the value of the contract to receive the rest of his money (Minasyan, G., 2013). To a large extent, the increasing indebtedness is a result of the avoidance of commitments and overdue payments by the state and municipalities to enterprises, despite the repeated desire of those responsible to undertake reforms to address this problem. Such an example is the creation of a mechanism for settling the obligations under the state budget (PMS 197, 2010). The idea of the mechanism is for the Bulgarian Development Bank to acquire the receivables of the state institutions to the creditors. To date, it is not clear or available whether the mechanism performs its functions correctly and whether it is still used as a model for repaying the state's obligations to its creditors, including private ones. Another initiated reform is the change in the Commercial Law and the introduction of a 60-day maximum term for repayment of an incurred obligation, and when the contracting authority is a public body - 30 days. On the other hand, according to a report of the National Audit Office at the end of 2016, the 


\section{Articles}

National Revenue Agency has to collect 29.8 billion leva or this is the amount of overdue total public receivables, and in 2015 the amount is over 32 billion leva. The National Revenue Agency is the creditor for 26 billion leva. The unpaid amounts by the enterprises are mainly for unpaid taxes (VAT, customs duties, excises) with accrued interest for arrears, as well as fees and social security contributions. As these are taxes owed by businesses, it is assumed that a small part of them are owed by other types of taxpayers. According to the Court's report, about $85 \%$ of these debts are uncollectible or difficult to collect. receivables with a 10 -year statute of limitations and in 2016 alone they amounted to 10 billion leva (Court of Auditors, 2019). Tax liabilities during the period under review increased from 3.8 billion to 4.4 billion leva, which should be a result of the increased volume of trade transactions. It should be borne in mind that when applying for projects funded by the EU, one of the mandatory conditions is that the applicant beneficiaries do not have current obligations to the state and municipalities.

\section{Conclusion and future research}

The topic of corporate and intercompany indebtedness is relevant, interesting and significant for the financial practice. The ability to deal with the problems of outstanding debts between companies will be determined by access to financial resources. Intercompany indebtedness in Bulgaria has existed as a problem for a long time, but this issue has really been addressed after the consequences of the financial and economic crisis. The increase in intercompany liabilities is not a factor for a recession, but a result of it. The main conclusions of the study are in several areas. Although corporate and intercompany indebtedness have high absolute values in the last 2018 and reached the levels of
Corporate Indebtedness of Non-Financial Corporations

in Bulgaria

2014, this does not give cause for concern. There are several reasons. First, when you measure what total and intercompany debt a company has, it turns out that the levels are even lower than in previous years. Second, if we consider the double and triple write-offs of liabilities by companies that have intra-firm understandings, inter-firm indebtedness will be much lower in absolute terms. A more worrying fact about intercompany indebtedness is that it is increasing as a share of total debt at the expense of lending by financial institutions, and these levels should be monitored more closely. However, in the last surveyed year, companies are applying for a higher amount of bank loans compared to the previous few years, which will stimulate their investment activity. This is a key moment for the future of non-financial corporations in Bulgaria, because investments decreased significantly in the period 2008-2018 both in absolute terms and as a percentage of GDP. Evidence of the improved situation with corporate indebtedness are the results of the survey. Examples of declining levels of indebtedness are argued by: 1) reducing the ratio of financial leverage, 2) reducing the ratio of liabilities to net sales revenue, 3 ) reducing the ratio of liabilities to receivables, 4) increasing interest coverage to gross profit. All this leads to two main and essential conclusions: first, examined only by absolute values, the information on the levels of corporate indebtedness is misleading, so a toolkit of indicators is needed for more accurate measurement and evaluation of its levels and second, that if not judged only at its nominal values, the situation with corporate and intercompany indebtedness has improved in recent years due to the above-mentioned relative results, which gives a chance to nonfinancial companies to achieve higher financial results, which leads to lower financial risk and higher financial autonomy and independence. This proves the author's thesis that if relative 


\section{Articles}

indicators are not applied and the number of enterprises participating in the analysis in different years is not considered, the results will be misleading. Nevertheless, the obtained results give grounds to strengthen the view, advocated here and in the rest of the academic literature, that each sector has its own individuals and there is no definite rights or inverse proportionality between general absolute indicators, absolute indicators of a company and relative indicators in each case. But it has been unequivocally shown that corporate indebtedness should not be judged by just one of the three approaches to analysis. Despite the improving results, the debt of Bulgarian non-financial corporations remains too high, as evidenced by the high levels of intercompany indebtedness as a share of total and based on the debt-toequity ratio. In the future, the interdependence will be sought in the implementation of the respective measures and what impact they will have and how they will interact if some of them are applied at once and if they are not applied. Research on the topic, which the author plans, is related to the study of the impact of the CoVid-19 crisis on corporate indebtedness, and for this purpose the respective econometric model is built and tested. Unfortunately, the statistical information will be available 3 or 4 years later. Creating a model for unification and thus comparing the units of measurement for absolute, relative and qualitative indicators using the so-called. rating tables is an ambitious but feasible task, the solution of which the author will seek in his next analysis on the topic of corporate indebtedness.

\section{References}

Adachi-Sato, M., Vithessonthi, Ch. 2019. Corporate debt maturity and future firm performance volatility. International Review of Economics and Finance. 60: 216-237
Beev. I. 2017. Macroeconomic functions of the state in the context of legal regulations. Sofia: UNWE Publisher (In Bulgarian)

Bulgarian Chamber of Commerce and Industry, https://www.bcci.bg

Bulgarian Industrial Association. 2014. Liabilities of enterprises in the non-financial sector of the economy. Annual report 01.2014, Sofia, www.bia-bg.com (In Bulgarian)

Bulgarian National Bank, https://www.bnb.bg/ Statistics/index.htm

Cecchetti, St., Mohanty, M., Zampolli, F. 2011. The Real Effects of Debt. Bank of International Settlement, www.bis.org

Cole, R. 2010. Bank Credit, Trade Credit or No Credit: Evidence from the Surveys of Small Business Finances. MPRA, Munich

Di Fiore, F., Uhlig, H. 2015. Corporate Debt Structure and the Financial Crisis. ECB. N.1759, 2015, February

European central Bank. Debt of non-financial Corporation. Explanation of alternative measurement concepts. https://www.ecb. europa.eu/

European Commission. 2017. Council Recommendation on the 2017 National Reform Programme of Bulgaria, COM (2017) 502 final, 2017 / C 261/02

European Commission. 2018. Council Recommendation on the 2017 National Reform Programme of Bulgaria, COM (2018) 402 final, 2018 / C 320/02

Giannetti, C. 2019. Debt specialization and performance of European firms. Journal of Empirical Finance. (53): 257-271

Hristov, M. 2013. Fundamentals of Finance. Sofia: VUZF (In Bulgarian)

Hristozov. Y. 2014. Modern approaches for management and control of the financial cycle as an indicator of liquidity in the enterprise. Conference: Contemporary 


\section{Articles}

problems in the theory and practice of control in Bulgaria. UNWE, 156-169 (In Bulgarian)

Minassian, G. 2013. Indebtedness and macroeconomic imbalances. Economic. Economic Research Institute. Sofia: BAS (In Bulgarian)

National Statistics Institute, https://www.nsi.bg Nenkov, D. 2016. Growth Policy and Value Creation in Companies, Economic Studies Journal, (4):36-65 (In Bulgarian)

Nenkov, D., Hristozov, Y. 2020. Corporate Finance. Textbook. Sofia: UNWE Publisher (In Bulgarian)

Orman, C., Koksal, B. 2017. Debt maturity across firm types: Evidence from a major developing economy. Emerging Markets Review. (30): 169-199

Taseva, G. 2016. Market Power of Firms and Measures against overdue Accounts Receivables. Anniversary scientific conference with international participation. BFU, 127-137 (In Bulgarian)

Trifonova, S. 2016. Estimation of the Factor Impact of Indebtedness and Solvency on
Corporate Indebtedness of Non-Financial Corporations

in Bulgaria

Enterprises Efficiency. Yearbook D. A. Tsenov - Svishtov, (119): 135-206. (In Bulgarian)

Raykov, E. 2017. Integrated approach to working capital management in the financial and economic crisis, monographic study. Sofia: UNWE Publisher (In Bulgarian)

Welth, I. 2009. Corporate Finance. An Introduction. Prentice Hall, New York

Yankov, I. 2016. Endogenous Elements of the Firm Indebtedness in Bulgaria. Economic Studies Journal, Bulgarian Academy of Sciences - Economic Research Institute, (1): 126-140.

Yankov, I. 2014, "Indebtedness in Bulgaria Trends and Comparisons with the Countries of Southeastern Bulgaria", Institute for Economic Policy, ed. Simolini - 94, Sofia: 41-53

* This article contains results of a study funded by a targeted subsidy of the University of National and World Economy under contract NID NI-4/2018, led by Yanko Hristozov. 